\title{
FACTORS DETERMINING THE VULNERABILITY OF WOMEN TO SEXUALLY TRANSMIT- TED HIV: A LITERATURE REVIEW
}

\section{Leslie Macleod-Downes}

MSc Nursing, Advanced Diploma in Nursing Education, Diploma in General \& Psychiatric Nursing, Diploma in Midwifery, Certificate in Community Health Nursing \& Primary Health Care Ward Manager, Sezincote Ward, Charlton Lane Centre, Charlton Lane, Cheltenham, Gloucestershire, GL53 9DZ At time of research: Founder Trustee, Robin Trust (South Africa), PO Box 375, Howard Place, 7450, South Africa

\section{Ruth M Albertyn}

$\mathrm{PhD}$ (Education), MConSc (Adult Education), HonsConSc, BConSc (Ed)

Researcher: Centre for Higher and Adult Education, Faculty of Education, University of Stellenbosch, Private Bag $\mathrm{X} 1$, Matieland

Corresponding author: rma@sun.ac.za

\section{Pat Mayers}

MSc Med (Psych), BA Cur (Nursing Education and Community Health), BVerpleegkunde, Diploma in Psychiatric Nursing, Diploma in Midwifery

Senior Lecturer, School of Health and Rehabilitation Sciences, University of Cape Town, Faculty of Health Sciences, Anzio Road, Observatory

Keywords: gender vulnerability; females; empowerment; indicators; human immunodeficiency virus (HIV)

\begin{abstract}
Gender-related vulnerability is described as a crucial factor contributing to increased susceptibility of women to HIV, accounting for more women than men being infected. At the same time, empowerment interventions are being promoted as effective strategies for increasing the ability of women to adopt protective behaviours. The aim of the review was to identify, collate and categorise the factors determining the gender-related vulnerability of women to sexually transmitted HIV. A review of literature from theoretical and empirical studies using diverse methodologies was undertaken. Reports included those identified through electronic and manual searching. Twenty factors, forming five clusters, were identified as influencing the ability of women to adopt protective behaviours. Each factor was analysed to describe its component parts and the relationship between a factor, gender-related vulnerability, HIV risk level and empowerment status. Further analysis provided a description of markers named predictors and indicators. The literature portrays markers that can be identified and used to describe gender equality status, HIV risk level and related empowerment. This provides the potential to identify factors in gender equality status and HIV risk level to address in programmes designed to empower women in order to lower their risk to sexually transmitted HIV.
\end{abstract}

\section{OPSOMMING}

Geslagsverwante kwesbaarheid word beskryf as ' $n$ kritieke faktor wat tot verhoogde vatbaarheid van vroue vir MIV bydra, wat die verhoogde besmetting van vroue teenoor mans verklaar. Terselfdertyd word bemagtigingsintervensies aangemoedig as geskikte strategieë om vroue se vermoë om beskermende gedragspatrone aan te neem, te verhoog. Die doel van hierdie oorsig was om die faktore wat geslagsverwante vatbaarheid van vroue vir seksueel oordraagbare MIV bepaal, te identifiseer, vergelyk en kategoriseer. ' $n$ Literatuurstudie van teoretiese en empiriese studies wat ' $n$ verskeidenheid metodologieë gebruik het, is onderneem. Verslae bekom deur elektroniese en handsoektogte is inges/uit. Twintig faktore, wat in vyf groepe verdeel is, is geïdentifiseer as dié wat die vermoë van vroue om beskermende gedragspatrone aan te neem, beïnvloed. Elke faktor is ontleed om die samestellende dele 
en die verband tussen ' $n$ faktor, geslagsverwante kwesbaarheid, MIV-risikovlak en bemagtigingstatus te beskryf. Verdere analise het 'n beskrywing van merkers, genoem voorspellers en aanwysers, opgelewer. Die literatuur beskryf merkers wat geïdentifiseer en gebruik kan word om geslagsgelykheidstatus, MIV-risikostatus en verwante bemagtiging te beskryf. Dit bied die moontlikheid om faktore in geslagsgelykheidstatus en MIV-risikostatus te identifiseer wat aandag moet geniet in programme wat ontwerp is om vroue te bemagtig om hul risiko van seksueel oordraagbare MIV te verlaag.

\section{INTRODUCTION}

South Africa continues to have the largest number of people living with HIVIAIDS in the world with AIDS being one of the ten leading causes of death in 2005 (Statistics South Africa, 2007:19). Tuberculosis, the leading cause of death in South Africa in 2005, has a high prevalence of co-infection with HIV, and accounts for up to a third of AIDS deaths worldwide (World Health Organization, 2008:1). HIV prevalence, estimated to be $10.8 \%$ amongst persons aged two years and older, increases dramatically among young females and peaks at $33.3 \%$ of the $25-29$ age group (Pettifor, Rees, Kleinschmidt, Steffenson, MacPhail, HlongwaMadikizela, Vermaak \& Padian, 2005:1526; Shisana, Rehle, Simbayi, Parker, Zuma, Bhana, Connolly, Jooste \& Pillay, 2005:124, 135). Gender issues related to a woman's place in South African society is described as an important factor contributing to the rapid spread of HIV in this region. This is due to unequal gender power relationships fuelled by negatively scripted, culturally defined gender roles and poverty. This lack of power of women within their social and economic contexts thus needs to be addressed within the HIV discourse. Empowerment is considered to be the key to enabling women to protect themselves from HIV infection (Bentley, 2004:257; Shearer, Hosterman, Gillen \& Lefkowitz, 2005:312; Greig \& Koopman, 2003:195; Ackermann \& De Klerk, 2002:163; Buvé, BishikwaboNsarhaza \& Mutangadura, 2002:2013; Kim \& Motsei, 2002:1248; Doyal, 2001:1061-1063; Umerah-Udezulu, 2001:5; Amaro \& Raj, 2000:724; Parker, Easton \& Klein, 2000:S23-S24; Pettifor, Measham, Rees \& Padian, 1996:2003; Preston-Whyte, 1995:218). The problem seems to be the unequal gender power relationship, which makes women more vulnerable to HIV infections and this will be examined in more detail.

This article describes a literature review undertaken to identify the factors influencing the ability of women to adopt safe sexual practices. The purpose of this review is to provide background information, as part of a larger study, for planning a holistic HIV intervention aimed at empowering women. To design such an intervention, it is important to understand the context, challenges and choices of women in South Africa (Stadler, Delany \& Mntambo, 2008:189-190). Thus the framework reported in this study will be used as a tool for planning an intervention for the empowerment of women within the context of HIV in South Africa.

The literature review was based on an approach described by Kirkevold (1997:981) as a synthesis review, a method whereby isolated information is integrated into a "more comprehensive and internally consistent whole". This enables the integration of separate studies with a different focus and using a variety of methodologies that provide a comprehensive account of the phenomenon being reviewed. Kirkevold (1997:981) argues that this type of review is a powerful knowledge development tool, as it enables knowledge to be accumulated that is "beyond merely evaluating the strength and weaknesses of existing knowledge".

\section{SEARCH METHODS}

The search was of literature from 1995-2007. The SWICE database was used, which searches AMED, BNID, CINAHL, DH DATA, EMBASE, KINGS FUND, MEDLINE and PsychoINFO. The search terms used were 'HIV', 'women', 'vulnerability', 'South Africa' and 'southern Africa'. Manual searching revealed further literature and reports were added as they were published. Primary studies, review articles, international and national reports, and national policy documents were included. A primary study was defined as primary empirical research including studies using qualitative and quantitative methods (Whittemore \& Knafl, 2005:546547; Kirkevold, 1997:983). The following inclusion criteria for literature sources were applied:

- the study reported on women's ability to choose and/or adopt protective behaviours in hetero- 
sexual relationships;

- it identifies predictors or indicators of safety or risk to sexually transmitted HIV between heterosexual couples;

- $\quad$ it was conducted in southern Africa;

- a study undertaken elsewhere which explicated the topic in more depth than the regional data; and

- $\quad$ studies available in English.

It was decided that the value of the article in providing insight into the contributors of either safe or unsafe sexual practices would serve as the primary selection criterion. For the identification and/or confirmation of factors in the various clusters, 91 articles were consulted.

\section{DATA ANALYSIS}

Literature sources were analysed using a constant comparison method aiming to identify similarities and differences in the findings across the studies (Dellve, Abrahamsson, Trulsson \& Hallberg, 2002:140-141; Creswell, 1998:57). Through this process the findings from each study were coded, grouped into categories and compared with the original data to ensure that the fit was appropriate. The categories were then refined to create a description of 20 factors determining women's vulnerability to sexually transmitted HIV. Each identified factor was analysed to consider the effect of a status of empowerment or disempowerment on the factor. The primary researcher and two co-researchers (supervisors) categorised the literature and reached consensus on the identification of factors and clusters. It is acknowledged that bias may be evident owing to the constraints of access to literature, and this may be a limitation of a review of this nature in terms of generalisation to other contexts. However, this review has value within the broader framework of this study where the aim of the identification of factors is to assist in planning an intervention for the empowerment of women within the HIV context in South Africa.

\section{FINDINGS}

During the process of analysis of each of the factors and the influence of empowerment/disempowerment on each one, predictors and indicators emerged. Twenty factors, grouped into the following five clusters, were identified as determining the vulnerability of women to sexually transmitted HIV: bio-psychosocial and demographic factors, cultural and societal factors, communication factors, perceptions and self-efficacy (see Figure 1). This classification was selected based on examples of categories found in research questionnaires in the studies reviewed. Each factor was analysed to reveal its component parts, which were then classified as predictors of gender equality status or indicators of HIV risk level. This demonstrated the relationship between a factor, gender-related vulnerability and HIV risk status, while at the same time distinguishing between the effects of a status of empowerment (predictors of gender equality and indicators of low HIV risk) or disempowerment (predictors of gender inequality or indicators of high HIV risk) on each component (for examples see Figure 1 and Figure 2). Each of the five clusters and their concomitant factors will be discussed in more detail in the section that follows.

\section{Cluster 1: Bio-psychosocial and demo- graphic factors}

Bio-psychosocial and demographic factors, for the purposes of this review, include age, relationship status, school attendance, level of education, economic status, religious affiliation, ethnicity and race, geographical location of residence and living arrangements.

\section{Age}

While all sexually active females are at risk, young women are particularly vulnerable (Gilbert \& Walker, 2002:1094; Gregson, Nyamukapa, Garnett, Mason, Zhuwau, Carael, Chandiwana \& Anderson, 2002:1899; Department of Health [South Africa], 2000:8; UNAIDS, 2000:11; Gray, Wawer, Brookmeyer, Sewankambo, Serwadda, Wabwire-Mangen, Lutalo, Li, Van Cott, Quinn \& Rakai Project Team, 2001:1153; Pettifor et al., 1996:2003). Worldwide, half of all people who acquire HIV become infected before they are 25 years old. In South Africa the highest HIV prevalence rate is observed in women between 25 and 29 years (Shisana \& Simbayi, 2002:53). A predictor of risk emerged distinguishing between women over 31 years (lower risk) and those 30 years or younger (higher risk).

Indicators identified describe age differential between sexual partners, nature of sexual debut (forced or chosen), age at onset of sexual activity, and the nature of 


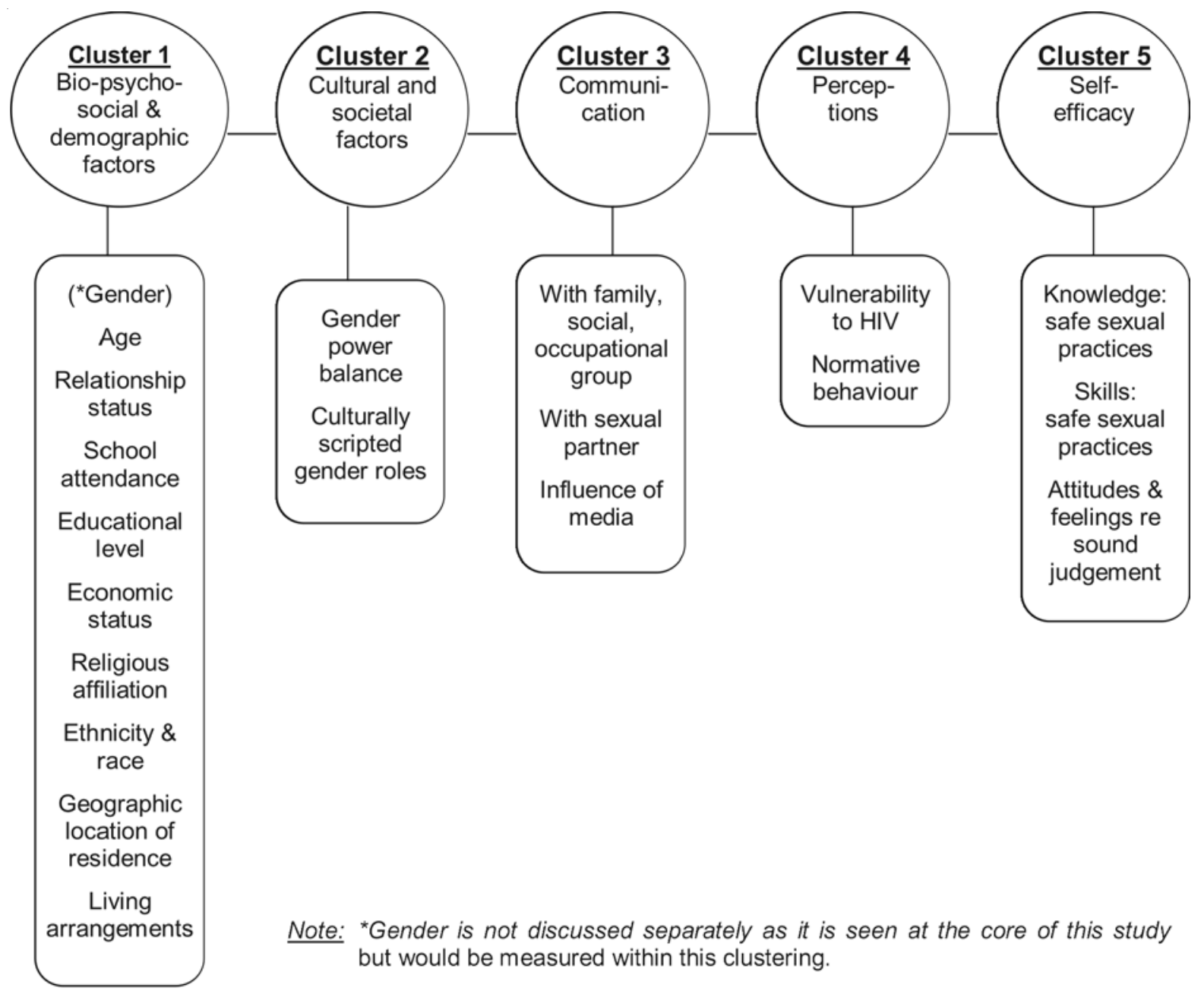

Figure 1: Summary of factors grouped as clusters

intercourse (forced, coercive or consensual) (Andersson, Ho-Foster, Matthis, Marokoane, Mashiane, Mhatre, Mitchell, Mokoena, Monasta, Ngxowa, Salcedo \& Sonnekus, 2004:954; Garbus, 2003:5; Buvé et al., 2002:2013-2014; Campbell \& Mzaidume, 2002:230; Gregson et al., 2002:1896; Shisana \& Simbayi, 2002:58, 69; Laga, Schwärtlander, Pisani, Sow \& Caraël, 2001:932-933; MacPhail \& Campbell, 2001:1615, 1621; UNAIDS, 2001:21-22; Vundule, Maforah, Jewkes \& Jordaan, 2001:73; Wood \& Jewkes, 1998:6, 8, 12; Wood, Maepa \& Jewkes, 1997:6, 11-12; Wood, Maforah \& Jewkes, 1996:3-5). These indicators were selected since sexual activity can be consensual and coerced. Sexual activity is associated with love, multiple partners, sexual desire, abuse, economic necessity and social pressure and increasingly an age differential of more than five years between a young woman and her older partner (Flisher, Reddy, Muller \& Lombard, 2003:540; Buvé et al.,
2002:2014; Gray, Wawer, Serwadda, Sewkambo \& Wabwire-Mangen, 1998:99; Laga et al., 2001:933; Nyanzi, Pool \& Kinsman, 2001:86-88; UNAIDS, 2001:23-24; Swart-Kruger \& Richter, 1997:958-961).

Biological immaturities of the genital tract as well as characteristics of the sexual practices of young women increase risk (Gray et al., 2001:1152). These characteristics include early sexual debut, multiple partners, a low incidence of condom use and a perception of being "invulnerable", which support the factor of partners with risk-taking behaviour (Karim, Magnani, Morgan \& Bond, 2003:14; Laga et al., 2001:933; Swart-Kruger \& Richter, 1997:963). Culture and tradition can place women at risk. Examples include taboos which do not allow older women to discuss sexual matters with younger women, and boys being encouraged to have multiple partners (Nyanzi et al., 2001:91; Wood et al., 1997:7). Peer influence is seen to be greatest for 


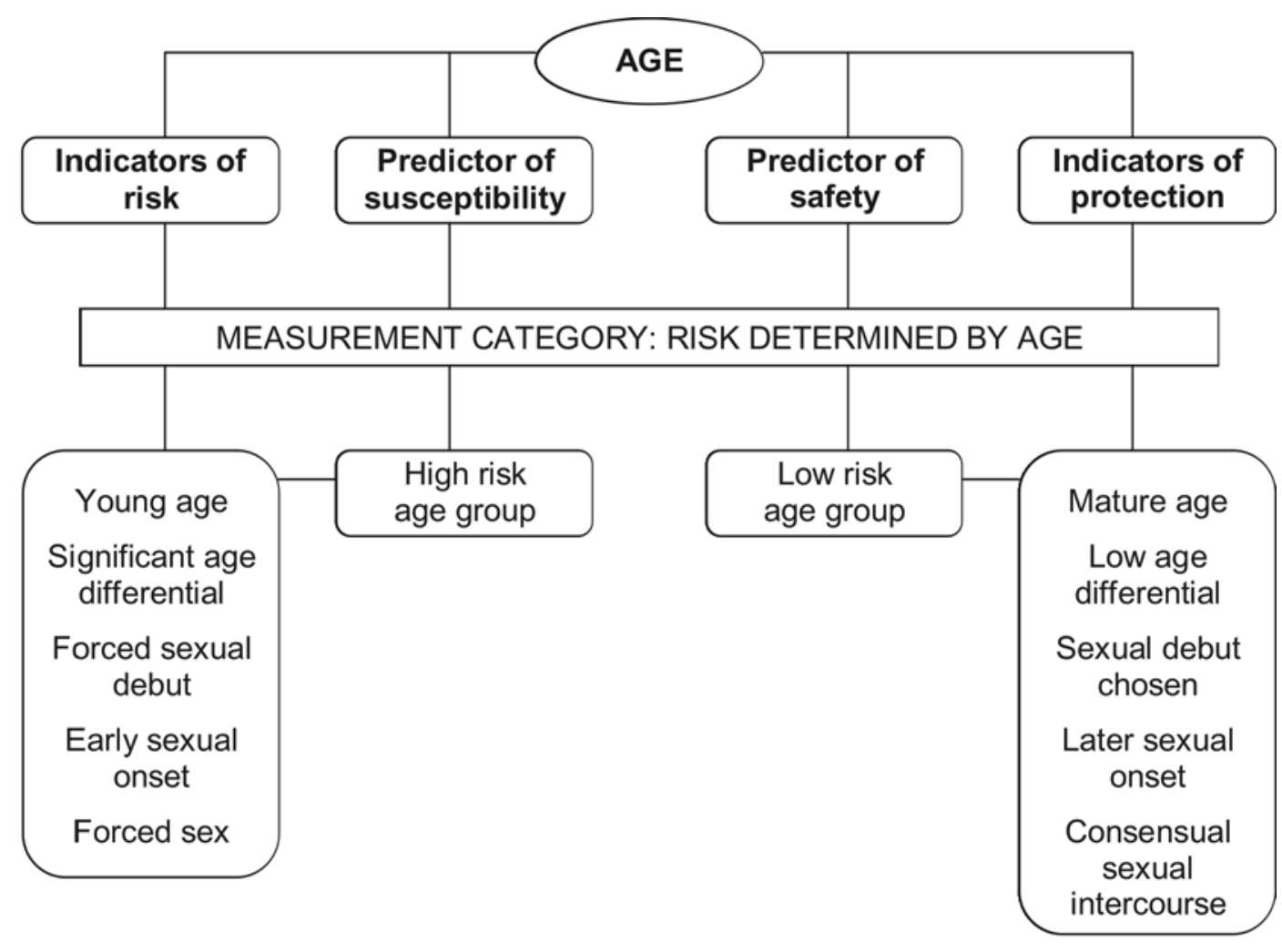

Figure 2: Summary of factor: Age

younger women (Eaton, Flisher \& Aaro, 2003:159-160; MacPhail \& Campbell, 2001:1621; Nyanzi et al., 2001:95-96). Alcohol consumption is also a particular risk factor for adolescents. Links have been made between being young, alcohol consumption, casual sex and inconsistent condom usage (Wong, Thompson, Huang, Park, Digangi \& De Leon, 2007:489; Garbus, 2003:6; Morojele, Kachieng, Mokoko, Nkoko, Parry, Nkowane, Kgaogelo \& Saxena, 2006:224).

\section{Relationship status}

Relationship status risk is predicted by the partners' commitment to the sexual relationship and women's scope for decision-making autonomy. Heterosexual intercourse, including between husband and wife, is the most common transmission route (Buvé et al., 2002:2014; Gray et al., 2001:1149-1153; UmerahUdezulu, 2001:5; Preston-Whyte, 1995:220). Predictors of risk describe commitment (faithfulness versus unfaithfulness) (Amaro \& Raj, 2000:724). Indicators distinguish between being monogamous as opposed to having multiple partners (concurrently, sequentially, known or unknown) and self-reports of sexually transmitted infections (STIs) as reported by Shelton,
Halperin, Nantulya, Potts and Gayle (2004:892), Gregson et al. (2002:1899), Mbulaiteye, Mahe, Whitworth, Ruberantwari, Nakiyingi, Ojwiya and Kamali (2002:41) and Bui, Pham, Pham, Hoang, Nguyen, Vu and Detels (2001:19-20). STIs are an indicator of unsafe sexual practices as they are associated with risky behaviour (El-Bassel, Witte, Gilbert, Wu, Chang, Hill \& Steinglass, 2003:988; Myer, Morroni, Mathews \& Little, 2002:199; Gray et al., 2001:1150; Cohen, 1998:57). Women in a committed relationship, including married women, are at risk as they may incorrectly assume themselves to be in a monogamous and therefore safe relationship (Bird, Harvey, Beckman, Johnson and The Partners Project, 2001:223; Amaro \& Raj, 2000:724).

Scope for decision-making differentiates between predictors describing relationships that restrict decisionmaking compared with ones that allow for autonomous decision-making. Linked indicators describe the practice of abstinence, marital status, age at first marriage and whether marriage was arranged or chosen by the woman (Zellner, 2003:41; Gregson et al., 2002:18971899; Mbulaiteye et al., 2002:41). 


\section{School attendance}

In developing countries school attendance is a predictor of the cultural value attached to being a girl and a mother's belief in education for her daughter. Non-attendance or infrequent attendance leads to economic dependence and lowers future prospects (Grown, Gupta \& Pande, 2005:541). Adolescent and young women occupied by school activities are less likely to be engaged in sexual activity. However, sexual exploitation of girls at school places them at risk (Shisana \& Simbayi, 2002:63; Human Rights Watch, 2001:1, 36, $61)$. School provides an opportunity for education on sex and HIV, therefore a lack of formal schooling can be seen as increasing vulnerability to HIV (Grown et al., 2005:541; Blake, Ledsky, Goodenow, Sawyer, Lohrman \& Windsor, 2003:958-961; Blum, Halcon, Buehring, Pate, Campbell-Forester \& Venema, 2003:459; Karim et al., 2003:18; Lum, Kristen, Ochoa, Judith, Hahn, Shafer, Evans \& Moss, 2003:919-920; Department of Health [South Africa], 2000:8; SwartKruger \& Richter, 1997:958; Araoye \& Adegoke, 1996:181). Indicators identified are school attendance, affordability of school fees, gender bias and sexual exploitation at school.

\section{Level of education}

Educational level is a predictor of gender power and role (Grown et al., 2005:541). Low educational levels are associated with an increase in vulnerability and risk resulting from fewer life opportunities, poor nutrition and hygiene, higher mortality, lower fertility rates and lower economic development (Kongolo \& Bamgose, 2002:86; Bowleg, Belgrave \& Reisen, 2000:614).

\section{Economic status}

Garbus (2003:3) found that economic status correlates directly with HIV prevalence where the greatest number of persons infected is situated at the lowest socio-economic point and HIV prevalence decreases with rising economic status. Girls and women face particular risks of HIV infection as the interplay between their economic positions and social status influences the decisionmaking authority given to them. Therefore the predictor describes income status and the indicators are employment status, income bracket and ability to support dependants (Grown et al., 2005:542; Buvé et al., 2002:2014, 2016; Gilbert \& Walker, 2002:1103; Kehler, 2001:1; Amaro \& Raj, 2000:724; Preston-Whyte, 1995:220). Financial dependence and poverty are criti- cal in determining whether sex will be exchanged as a commodity, as transactional sex limits decision-making ability and the scope for negotiating safe sexual practice. Sex trafficking is increasingly being associated with South Africa and places victims at risk of HIV. A predictor of risk is the practice of transactional sex and the indicators describe reports covering exchange of sex for gain, sex trafficking and scope for negotiating safe sexual practice (Shelton et al., 2004:892; Garbus, 2003:35; Buvé et al., 2002:2014; Jewkes \& Abrahams, 2002:1232; Wojcicki \& Malala, 2001:102; Gutierrez, Oh \& Gillmore, 2000:582; Preston-Whyte, 1995:218).

HIV risk linked to employment is the predictor of occupational risk. Indicators differentiate between work associated with HIV risk, such as hospital workers, and workers who, owing to the nature of their jobs, are at increased risk (e.g. migrant workers and truckers).

\section{Religious affiliation}

The teachings of religion are reported to influence the value men attach to women, age of sexual onset and practices such as abstinence. There has been limited reporting on the impact of traditional African beliefs on HIV transmission. Findings suggest that 'fatalism' and an understanding of ill-health linked to 'angry ancestors' contribute significantly to the lack of understanding of HIVIAIDS in sub-Saharan Africa (Gray, 2004:17511756; Blum et al., 2003:458; Eaton et al., 2003:158; Potts \& Walsh, 2003:1390; Stadler, 2003:358; MacPhail \& Campbell, 2001:1614; Lagarde, Enel, Seck, GueyeNdiaye, Piau, Pison, Delaunay, Ndoye \& Mboup, 2000:2028-2029; Rankin \& Wilson, 2000:1543-1544; Wood \& Jewkes, 1998:9; Caldwell, Orubuloye \& Caldwell, 1992:1169).

The religious socio-cultural context can influence women's rights through either promoting or limiting equality of opportunities. The predictors distinguish between a context that is non-discriminatory and one that discriminates against women. This is indicated through religious guidelines (doctrine) that support or disregard gender equality and indicate level of gender inclusiveness. The predictor of religious teaching distinguishes between teaching that supports/enables gender equality or contributes to gender inequality. Indicators describe religious teaching on gender and safe sex, as well as practices harmful to women. 


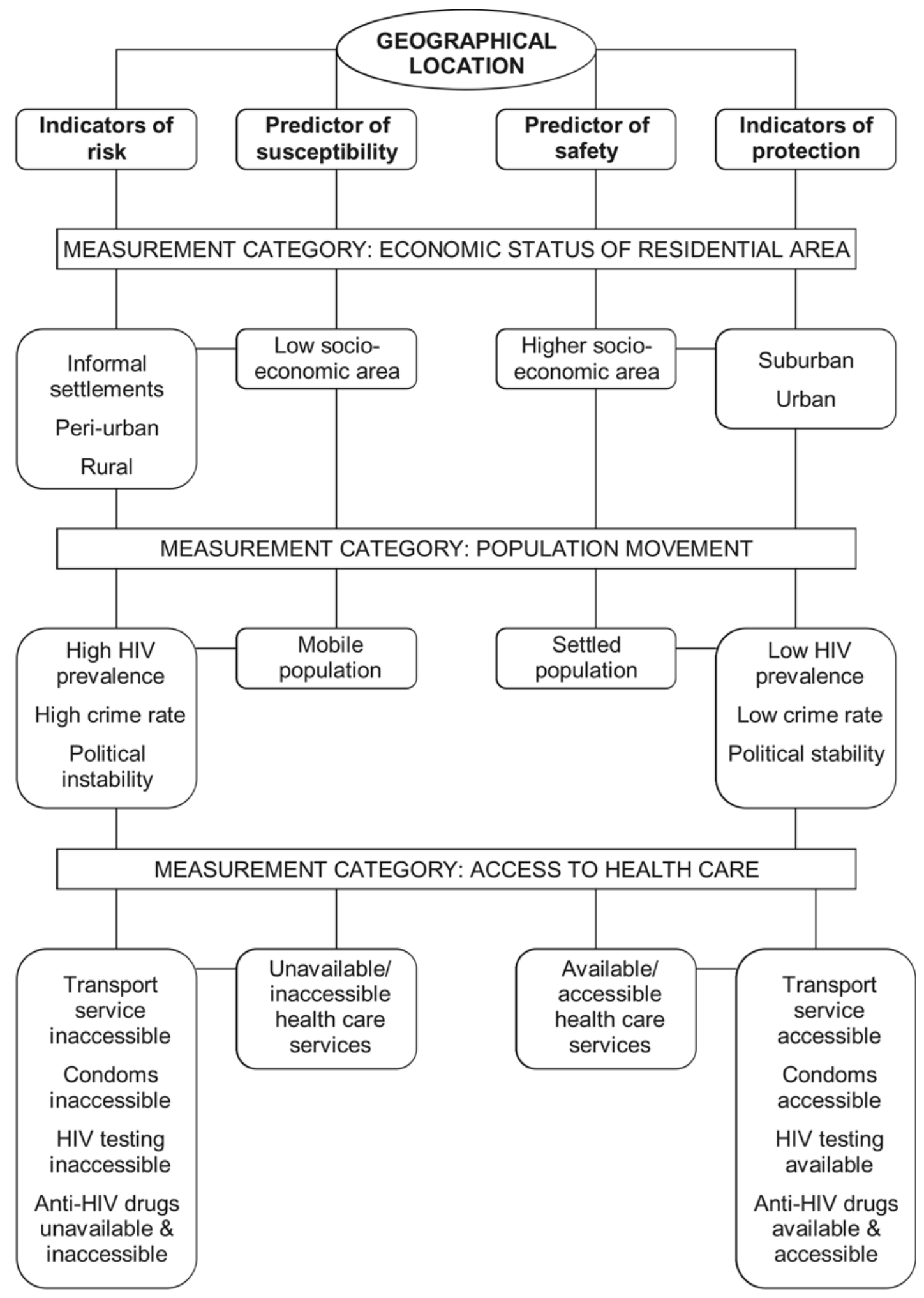

Figure 3 Summary of factor: Geographical location (includes region and residence)

\section{Living arrangements}

This category measures whether living arrangements offer protection from unwanted sexual assault. Vulnerability is linked to lack of protection and behaviours such as incest, sleeping 'rough' and being in prison (for males). Identified risk behaviours include earlier sexual debut, more sexual partners, rape and forced sexual activity as part of survival as well as lower condom use. Adolescents on the street are often non-school attendees, with higher rates of illiteracy and less expo- 
sure to accurate sex information (Eaton et al., 2003:160; Wood \& Jewkes, 1998:12-15, 36; SwartKruger \& Richter, 1997:958). Indicators distinguish between an environment offering protection and one that does not do so, as well as the type of dwelling in which a woman lives. Studies by Swart-Kruger and Richter (1997:964) and Eaton et al. (2003:160) provide evidence that women living with strangers, in institutions or on the street are particularly vulnerable. Females living in any setting, however, including their homes, are at risk owing to sexual assault.

\section{Cluster 2: Cultural and societal factors}

Cluster 2 comprises gender power balance and culturally scripted roles.

\section{Gender power balance}

Power balance is the predictor and the indicators describe who controls the power, the distribution of power and whether negative consequences of requests for condom use will be a barrier to safe sexual practice. Male dominance and unequal power distribution which are linked to risk behaviours include men who control sexual encounters, women are unable to influence how and when sex takes place, and sexual coercion with physical or emotional pressure or violence. Violence includes sexual assault, rape and marital rape, all of which place women at an increased risk of HIV infection owing to damage to the female genital area, nonuse of condoms, exposure to multiple partners in 'gang' rape and a situation in which sexual negotiation is extremely difficult (Jones \& Oliver, 2007:812; Campbell, Foulis, Maimane \& Sibiya, 2005:813; Shearer et al., 2005:322; Tiessen, 2005:14; Andersson et al., 2004:952; Greig \& Koopman, 2003:197; Kim \& Motsei, 2002:1251; Umerah-Udezulu, 2001:4; UNAIDS, 2001:23-24; Vundule et al., 2001:73; Amaro \& Raj, 2000:726; Wood \& Jewkes, 1998:12-15, 24; Pettifor et al., 1996:1996).

\section{Culturally scripted roles}

The cultural milieu provides the context and describes the culturally prescribed role of women that either upholds or infringes the rights of women. The value given to the female role portrays women as valued or devalued. The subordinate female position entrenched in many African societies limits the control women have over their own sexual choices and over their husbands' behaviour outside of marriage. This vulnerability to HIV is exacerbated by extramarital affairs, which may be accepted and even encouraged as a show of masculinity through early sexual initiation and many sexual conquests. Roles that emphasise innocence, virginity, submission to male prerogative, low status, erotic fantasy, myth (cure of HIV by having sex with a virgin), ignorance, lack of knowledge regarding sex and HIV are harmful to women (Shearer et al., 2005:320; Andersson et al., 2004:955; Buvé et al., 2002:2014-2016; Kim \& Motsei, 2002:1247; Umerah-Udezulu, 2001:4; Bujra, 2000:13-14; Jewkes, Penn-Kekana, Levin, Ratsaka \& Schrieber, 1999:3, 8, 23). Therefore the indicators describe whether women are accepted as equal partners or as subordinates and how the media, a powerful shaper of opinion, portrays the value of women.

The Constitution of the Republic of South Africa 108 of 1996 upholds the rights of individuals and therefore anything limiting this is an infringement (quoted by Bentley, 2004:247). Patterson and London (2002:966) motivate for an approach to supporting human rights that also responds to a socio-economic rather than a simplistic "libertarian approach" to rights. The indicators describe the impact of rights being upheld for people who are HIV positive (Bentley, 2004:257). Stigmatisation is an infringement and fear of being stigmatised can be a barrier for people who wish to know their HIV status through HIV testing or to disclose their positive serostatus (Campbell et al., 2005:812-813; Burke, 2004:423; Parsons, Vanora, Missildine, Purcell \& Gomez, 2004:459). Stigma can have serious consequences such as isolation and neglect, further increasing the burden on women. Many keep silent for fear of being identified, which prevents them from seeking treatment that could prolong life (Garbus, 2003:33; Lanouette, Noelson, Ramamonjisoa, Jacobson \& Jacobson, 2003:918-919; Stein, 2003:2-3; Umerah-Udezulu, 2001:6; Mathews, Kuhn, Fransman, Hussey \& Dikweni, 1999:1238). However, human rights of an individual, when respected and upheld, promote social inclusion of people who are HIV positive as well as an increase in disclosure.

\section{Cluster 3: Communication}

The third cluster refers to communication with family, friends, colleagues, sexual partners and the influence of media messages. 
Communication within the primary group, including family, friends and work colleagues, determines the level of information girls and women have regarding sexual issues and HIV. The predictor therefore describes whether women are informed or uninformed. Indicators describe communication style, information covering sexual matters, HIV and knowing the partner's HIV serostatus (Bird et al., 2001:234; Amaro \& Raj, 2000:736)

Communication with a sexual partner is predicted by communication style with indicators being discussion on sexual matters, HIV and safe sexual practices (Bird et al., 2001:234; Amaro \& Raj, 2000:736). The influence of media on female empowerment refers to the portrayal of women by the media as well as messages relayed on practices that are harmful to women and sexual practices (Keller \& Brown, 2002:68).

\section{Cluster 4: Perceptions}

This cluster refers to how individuals perceive their own vulnerability to HIV and the influence of normative behaviour.

\section{Perception of vulnerability to HIV}

A determinant of sexual practice is a woman's perception of her risk. Being in a committed relationship is associated with a perception of low HIV risk (Amaro \& Raj, 2000:724). HIVIAIDS complacency can be defined as minimising, discounting and discrediting the threat of HIVIAIDS and can lead to inaccurate assessments of personal risk. This may decrease motivation to adopt safe sexual practices although it might increase disclosure of an HIV-positive status to a partner (Burke, 2004:422; Parsons et al., 2004:471; Amaro \& Raj, 2000:725). Knowing someone who has HIV or who has died from AIDS is hypothesised to increase awareness of HIVIAIDS and its threat to personal health (Camlin \& Chimbwete, 2003:231; Shisana \& Simbayi, 2002:87), yet many South Africans do not know their own serostatus despite having access to voluntary counselling and testing (Shisana \& Simbayi, 2002:66). Refusal to test for HIV status is most often linked to concerns related to stigmatisation in the event of testing positive (Garbus, 2003:23). Women perceiving themselves at a low risk of HIV infection are not highly motivated to be tested for HIV (Garbus, 2003:33; Agha, 2002:113; Bird et al., 2001:234; Amaro \& Raj, 2000:740; Bowleg et al., 2000:630; Gutierrez et al., 2000:583; Reid,
2000:713; Coleman \& Mngomezulu, 1999:1060; SwartKruger \& Richter, 1997:962).

\section{Influence of normative behaviour}

The predictor reflects the influence of peers on safe sexual behaviour. Indicators include the influence of normative behaviour, perception of whether the benefits outweigh the costs and intention expressed regarding the adoption of safe sexual practices (Tiessen, 2005:16; Eaton et al., 2003:161; Karim et al., 2003:22; Amirkhanian, Kelly, Kukharsky, Borodkina, Granskaya, Dyatlov, Mcauliffe \& Kozlov, 2001:410; MacPhail \& Campbell, 2001:1614; Nyanzi et al., 2001:95; Marin, Gomez \& Tschann, 1993:742).

\section{Cluster 5: Self-efficacy}

Self-efficacy describes the confidence and competence to practise safe sex and covers the application of knowledge, the skills needed to practise safe sex and the attitudes and feelings influencing decision-making and therefore contributing to sound judgement.

\section{Application of knowledge}

Knowledge can be defined as a more general indicator in the communication cluster, but in this category it describes the application of accurate, complete and applied knowledge as evidenced by safe sexual practices tested through self-reports (Eaton et al., 2003:151; Garbus, 2003:40; Lanouette et al., 2003:918; Amirkhanian et al., 2001:410; Du Plessis, Muller, Poolman, Viljoen, Barnes \& Cotton, 2000:963; SwartKruger \& Richter, 1997:962-963; Araoye \& Adegoke, 1996:181).

\section{Practice}

Self-efficacy refers to the confidence and competence of an individual to practise safe sex. It includes the intention and application of skills (Rose, 2004:25; Eaton et al., 2003:158). Skills include the ability to resist sexual advances, negotiating condom use and correct and consistent condom use (Eaton et al., 2003:159). Alcohol use is associated with increased sexual risk behaviour, such as condom non-use (Eaton et al., 2003:159; Karim et al., 2003:18; Morrison, Gillmore, Hoppe, Gayford, Leigh \& Rainey, 2003:162; LaBrie, Schiffman \& Earlywine, 2002:145). 


\section{Attitudes and feelings contributing to sound judgement}

Attitudes relating to the self play an important role in sexual choices. Low self-esteem and feelings of poor self-worth have been linked to early sexual debut and a need to have multiple sexual partners as a way of selfaffirmation (Eaton et al., 2003:157-158). Self-esteem and self-confidence increase assertiveness (Rose, 2004:27). Rose (2004:25) states that feelings of selfworth and confidence give a feeling of being safe to make choices for behaviours that are protective.

\section{DISCUSSION}

This integrated review of the literature attempted to describe the factors determining women's vulnerability to sexually transmitted HIV. A challenge of the review was finding a method to deal with the volume of literature on the topic and the emphasis on a subset (South African) and the perceived similarity to the population being studied.

There has been a proliferation in studies pertaining to HIV. These studies cover a wide spectrum including prevention, transmission, clinical trials and social and economic aspects. It is not possible to be sure that all relevant studies have been included in this review. Amendments to the findings were made as new information became available. For example, initially, school was classified as a protective factor, but studies indicating that in certain schools inappropriate behaviour by some teachers increased the vulnerability of girls required amendments to be made (Brookes, Shisana \& Richter, 2004:35, 39; Shisana \& Simbayi, 2002:83, 95).

According to Parker et al. (2000:S29-S30), it is feasible that research conducted in some parts of the developing world is also pertinent to issues encountered in inner city populations in the USA. The literature review described was undertaken as a prequel to a study in South Africa, so the emphasis was on studies from southern Africa. Therefore the findings may be most relevant to the region and would need to be tested in other settings before comment can be made as to this study's usefulness in other contexts or its generalisability. Cooper (1998:43) states that generalisability is increased in integrative reviews containing articles conducted at different times, places, with varying samples of ages and races, as well as studies applying different methodologies. In this study the references cited reflect this diversity.

This study sought to describe all the related factors associated with women having an increased susceptibility to HIV and to better understand how their resilience could be promoted. This could lead to the perception that only some people are vulnerable, but the reality is that anyone who has been exposed to the virus is at risk of contracting HIV. From the description provided it may appear that the factors are equal in all circumstances while the literature emphasises the pivotal role of gender, relationships, cultural and societal factors (examined in this study as relationship factors, gender power balance and culturally scripted roles).

The constant comparison method used in reviewing the various documents provided the categories and the predictors and indicators linked to each category. The process resulted in a description of the factors influencing the vulnerability status of women to HIV and the relationship between empowerment, as a facilitator promoting the adoption of protective behaviours and safe sex (Shearer et al., 2005:312; Greig \& Koopman, 2003:197; Amaro \& Raj, 2000:728).

The first aim of this study was to identify, collate and categorise the factors determining the gender-related vulnerability of women to sexually transmitted HIV. The 20 factors identified provided a comprehensive description of the factors influencing the gender-related vulnerability of women to sexually transmitted HIV, demonstrating the breadth and complexity of the factors that need to be addressed in HIV prevention programmes.

The second aim was to indicate the link between empowerment and each factor. Empowering aspects that would influence gender equality status and in turn inform HIV risk level were identified. These factors should be borne in mind when planning interventions for the empowerment of women within this context to minimise the risk of HIV infection. This finding supports the understanding that HIV prevention programmes will be most effective if they address gender empowerment issues as identified in this study rather than specific behaviours only (Di Noia \& Schinke, 2007:486; Greig \& Koopman, 2003:195; Petersen \& Swartz, 2002:1010; Parker et al., 2000:S27-S28). 


\section{CONCLUSION}

The literature demonstrates that empowerment is a facilitator promoting the ability of women to adopt safe sexual practices and the value of adopting an empowerment approach in HIV prevention programmes. The identification of the factors influencing the vulnerability of women to sexually transmitted HIV, with related predictors and indicators, enables planners to differentiate between a position of gender equality compared to gender inequality and between a high or low level of HIV risk, and so conduct an assessment of the level of HIV risk. Assessment will highlight areas of risk, thus promoting the use of targeted HIV prevention programmes. The indicators provide the potential to monitor and evaluate the effectiveness of projects or programmes designed to empower women while lowering their risk to sexually transmitted HIV.

\section{REFERENCES}

ACKERMANN, L \& DE KLERK, G 2002: Social factors that make South African women vulnerable to HIV infection. Health Care for Women International, 23(2):163-172.

AGHA, S 2002: A quasi-experimental study to assess the impact of four adolescent sexual health interventions in sub-Saharan Africa. International Family Planning Perspectives, 28(2):6770 \& 113-118.

AMARO, H \& RAJ, A 2000: On the margin: Power and women's HIV risk reduction strategies. Sex Roles, 42(7-8):723-749.

AMIRKHANIAN, Y; KELLY, J; KUKHARSKY, AA; BORODKINA, OI; GRANSKAYA, J; DYATLOV, RV; MCAULIFFE, TL \& KOZLOV, AP 2001: Predictors of HIV risk behaviour among Russian men who have sex with men: An emerging epidemic. AIDS, 15(3):407-412. ANDERSON, JE 2003: Condom use and HIV risk among US adults. American Journal of Public Health, 93(6):912-914.

ANDERSSON, N; HO-FOSTER, A; MATTHIS, J; MAROKOANE, N; MASHIANE, V; MHATRE, S; MITCHELL, S; MOKOENA, T; MONASTA, L; NGXOWA, N; SALCEDO, MP \& SONNEKUS, H 2004: National cross sectional study on views on sexual violence and risk of HIV infection and AIDS among South African school children. British Medical Journal, 329(7472):952-957.

ARAOYE, MO \& ADEGOKE, A 1996: AIDS-related knowledge, attitude and behavior among selected adolescents in Nigeria. Journal of Adolescence, 19(2):179-181.

BENTLEY, K 2004: Women's human rights and the feminisation of poverty in South Africa. Review of African Political Economy, 31(100):247-261.

BIRD, ST; HARVEY, SM; BECKMAN, LJ; JOHNSON, CH \& THE
PARTNERS PROJECT 2001: Getting your partner to use condoms: Interviews with men and women at risk of HIVISTDs. Journal of Sex Research, 38(3):233-241.

BLAKE, SM; LEDSKY, R; GOODENOW, C; SAWYER, R; LOHRMAN, D \& WINDSOR, R 2003: Condom availability programs in Massachusetts high schools: Relationships with condom use and sexual behavior. American Journal of Public Health, 93(6):955-962. BLUM, RW; HALCON, L; BUEHRING, T; PATE, E; CAMPBELL-FORESTER, S \& VENEMA, A 2003: Adolescent health in the Caribbean: Risk and protective factors. American Journal of Public Health, 93(3):456-460.

BOWLEG, L; BELGRAVE, FZ \& REISEN, CA 2000: Gender rules, power strategies and precautionary sexual self-efficacy: Implications for Black and Latino women's HIVIAIDS protective behaviours. Sex Roles, 42(7/8):613-636.

BROOKES, H; SHISANA, O \& RICHTER, L 2004: The national household HIV prevalence and risk survey of South African children. Cape Town: HSRC Publishers.

BUI, TD; PHAM, CK; PHAM, TH; HOANG, LT; NGUYEN, TV; VU, TQ \& DETELS, R 2001: Cross-sectional study of sexual behaviour and knowledge about HIV among urban, rural and minority residents in Vietnam. Bulletin of the World Health Organization, 79(1):15-21.

BUJRA, J 2000: Targeting men for a change: AIDS discourse and activism in Africa. Agenda, 44:6-23.

BURKE, J 2004: Infant HIV infection: Acceptability of preventive strategies in Central Tanzania. AIDS Education and Prevention, 16(5):415-425.

BUVÉ, A; BISHIKWABO-NSARHAZA, K \& MUTANGADURA, G 2002: The spread and effect of HIV-1 infection in sub-Saharan Africa. Lancet, 359(9322):2011-2017.

CALDWELL, JC; ORUBULOYE, IO \& CALDWELL, P 1992: Underreaction to AIDS in sub-Saharan Africa. Social Science and Medicine, 34(11):1169-1182.

CAMLIN, CS \& CHIMBWETE, CE 2003: Does knowing someone with AIDS affect condom use? An analysis from South Africa. AIDS Education and Prevention, 15(3):231-244.

CAMPBELL, C; FOULIS, C; MAIMANE, S \& SIBIYA, Z 2005: "I have an evil child at my house": Stigma and HIV management in a South African Community. American Journal of Public Health, 95(5):808-815.

CAMPBELL, C \& MZAIDUME, Y 2002: How can HIV be prevented in South Africa? A social perspective. British Medical Journal, 324(7331):229-232.

COHEN, MS 1998: Sexually transmitted diseases enhance HIV transmission: No longer a hypothesis. Lancet, 351(Supplement 3):5-7.

COLEMAN, R \& MNGOMEZULU, P 1999: Challenged by the small screen - Responding to HIV-positive people on video on Kwazulu- 
Natal. South African Medical Journal, 89(10):1060-1066. COOPER, HM 1998: Synthesizing research: A guide for literature reviews; $3^{\text {rd }}$ edition. California: Sage.

CRESWELL, JW 1998: Qualitative inquiry and research design. Choosing among the five traditions. Thousand Oaks: Sage.

CUMMINS, P 2002: Access to health care in the Western Cape. Lancet, 360(Supplement):S49-S50.

DELLVE, L; ABRAHAMSSON, KH; TRULSSON, U \& HALLBERG, LR-M 2002: Grounded theory in public health research. (In: Hallberg, LR-M ed. 2002: Qualitative methods in public health research - Theoretical foundations and practical examples. Lund: Studentlitteratur, pp137-173).

DEPARTMENT OF HEALTH (South Africa) 2000: HIVIAIDS/STD strategic plan for South Africa 2000-2005. Pretoria.

DI NOIA, J \& SCHINKE, SP 2007: Gender-specific HIV prevention with urban early-adolescent girls: Outcomes of the keepin' it safe program. AIDS Education and Prevention, 19(6):479-488.

DOYAL, L 2001: Sex, gender and health: The need for a new approach. British Medical Journal, 323(7320):1061-1063.

DU PLESSIS, JK; MULLER, JB; POOLMAN, M; VILJOEN, K; BARNES, JM \& COTTON, MF 2000: Awareness of HIV infection amongst pregnant women attending the Elsies River Antenatal Clinic. South African Medical Journal, 90(7):693-696.

EATON, L; FLISHER, AJ \& AARO, LE 2003: Unsafe sexual behaviour in South African youth. Social Science and Medicine, 56(1):149-165.

EL-BASSEL, LN; WITTE, SS; GILBERT, L; WU, E; CHANG, M; HILL, J \& STEINGLASS, P 2003: The efficacy of a relationship-based HIVISTD prevention program for heterosexual couples. American Journal of Public Health, 93(6):963-969.

FISHER, B; NEVE, H \& HERITAGE, Z 1999: Community development, user involvement and primary health care. British Medical Journal, 318(7186):749-750.

FLISHER, AJ; REDDY, P; MULLER, M \& LOMBARD, C 2003: Sexual behaviour of Cape Town high-school students. South African Medical Journal, 93(7):537-541.

GARBUS, L 2003: HIVIAIDS in South Africa. San Francisco: AIDS Policy Research Centre, University of California. http://ari.ucsf.edu/ programs/policy/countries/SouthAfrica.txt. (Accessed on 14 July 2006).

GILBERT, L \& WALKER, L 2002: Treading the path of least resistance: HIVIAIDS and social inequalities - A South African case study. Social Science and Medicine, 54(7):1093-1110.

GRAY, PB 2004: HIV and Islam: Is HIV prevalence lower among Muslims? Social Science and Medicine, 58(9):1751-1756.

GRAY, RH; WAWER, MJ; BROOKMEYER, R; SEWANKAMBO, NK; SERWADDA, D; WABWIRE-MANGEN, F; LUTALO, T; LI, X; VAN COTT, T; QUINN, TC \& RAKAI PROJECT TEAM 2001: Probability of HIV-1 transmission per coital act in monogamous, heterosexual,
HIV-1-discordant couples in Rakai, Uganda. Lancet, 357(9263):1149-1153.

GRAY, RH; WAWER, MJ; SERWADDA, D; SEWKAMBO, N; LI, C \& WABWIRE-MANGEN, F 1998: Population-based study of fertility in women with HIV-1 infection in Uganda. Lancet, 351(9096):98103.

GREGSON, S; NYAMUKAPA, C; GARNETT, G; MASON, P; ZHUWAU, T; CARAEL, M; CHANDIWANA, SK \&ANDERSON, RM 2002: Sexual mixing patterns and sex-differentials in teenage exposure to HIV infection in rural Zimbabwe. Lancet, 359(9321):1896-1903.

GREIG, FE \& KOOPMAN, C 2003: Multilevel analysis of women's empowerment and HIV prevention: Quantitative survey results from a preliminary study in Botswana. AIDS and Behavior, 7(2):195-208.

GROWN, C; GUPTA, GR \& PANDE, R 2005: Taking action to improve women's health through gender equality and women's empowerment. Lancet, 365(9458):541-543.

GUTIERREZ, L; OH, HJ \& GILLMORE, MR 2000: Toward an understanding of (em)power(ment) for HIV/AIDS prevention with adolescent women. Sex Roles, 42(7/8):581-611.

HUMAN RIGHTS WATCH 2001: Scared at school: Sexual violence against girls in South African schools. New York: Human Rights Watch, USA.

JEWKES, R \& ABRAHAMS, N 2002: The epidemiology of rape and sexual coercion in South Africa: An overview. Social Science and Medicine, 55(7):1231-1244.

JEWKES, R; PENN-KEKANA, L; LEVIN, J; RATSAKA, M \& SCHRIEBER, M 1999: "He must give me money, he mustn't beat me" - Violence against women in three South African provinces. Cape Town: Medical Research Council.

JONES, R \& OLIVER, M 2007: Young urban women's patterns of unprotected sex with men engaging in HIV risk behaviour. AIDS and Behavior, 11(6):812-912.

KARIM, AM; MAGNANI, RJ; MORGAN, GT \& BOND, KC 2003: Reproductive health risks and protective factors among unmarried youth in Ghana. International Family Planning Perspectives, 29(1):14-24.

KEHLER, J 2001: Women and poverty: The South African experience. Journal of International Women's Studies, 3(1):13 screens. http://www.bridgew.edu/SoAS/jiws/fall01/kehler.pdf. (Accessed on 24 January 2003).

KELLER, SN \& BROWN, JD 2002: Media interventions to promote responsible sexual behaviour. Journal of Sex Research, 39(1):67-73.

KIM, J \& MOTSEI, M 2002: "Women enjoy punishment": Attitudes and experiences of gender-based violence among PHC nurses in rural South Africa. Social Science and Medicine, 54(8):12431254.

KIRKEVOLD, M 1997: Integrative nursing research - An important 
strategy to further the development of nursing science and nursing practice. Journal of Advanced Nursing, 25(5):977-984. KONGOLO, M \& BAMGOSE, OO 2002: Participation of rural women in development: A case study of Tsheseng, Thintwa and Makhalaneng villages, South Africa. Journal of International Women's Studies, 4(1):79-91.

LABRIE, JW; SCHIFFMAN, J \& EARLYWINE, M 2002: Expectancies specific to condom use mediate the alcohol and sexual risk relationship. Journal of Sex Research, 39(2):145-153.

LAGA, M; SCHWÄRTLANDER, B; PISANI, E; SOW, PS \& CARAËL, M 2001: To stem HIV in Africa, prevent transmission to young women. AIDS, 15(7):931-934.

LAGARDE, E; ENEL, C; SECK, K; GUEYE-NDIAYE, A; PIAU, J-P; PISON, G; DELAUNAY, V; NDOYE, I \& MBOUP, S for the MECORA group 2000: Religion and protective behaviours towards AIDS in rural Senegal. AIDS, 14(13):2027-2033.

LANOUETTE, NM; NOELSON, R; RAMAMONJISOA, A; JACOBSON, S \& JACOBSON, JM 2003: HIV-and AIDS-related knowledge, awareness, and practices in Madagascar. American Journal of Public Health, 93(6):917-919.

LUM, PJ; KRISTEN, C; OCHOA, BA; JUDITH, A; HAHN, A; SHAFER, KP; EVANS, JL \& MOSS, AR 2003: Hepatitis B virus immunization among young injection drug users in San Francisco, California: The UFO Study. American Journal of Public Health, 93(6):919921.

MACPHAIL, C \& CAMPBELL, C 2001: "I think condoms are good but, aai, I hate those things": Condom use among adolescents and young people in a southern African township. Social Science and Medicine, 52(11):1613-1627.

MARIN, BV; GOMEZ, CA \& TSCHANN, JM 1993: Condom use among Hispanic men with secondary female sexual partners. Public Health Reports, 108(6):742-750.

MATHEWS, C; KUHN, L; FRANSMAN, D; HUSSEY, G \& DIKWENI, L 1999: Disclosure of HIV status and its consequences (Letter). South African Medical Journal, 89(12):1238.

MBULAITEYE, S; MAHE, C; WHITWORTH, J; RUBERANTWARI, A; NAKIYINGI, J; OJWIYA, A \& KAMALI, A 2002: Declining HIV-1 incidence and associated prevalence over 10 years in a rural population in south-west Uganda: A cohort study. Lancet, 360:41-46. MOROJELE, NK; KACHIENG, MA; MOKOKO, E; NKOKO, A; PARRY, CDH; NKOWANE, AM; KGAOGELO, M \& SAXENA, S 2006: Alcohol use and sexual behaviour among risky drinkers and bar and shebeen patrons in Gauteng province, South Africa. Social Science and Medicine, 62:217-227.

MORRISON, DM; GILLMORE, R; HOPPE, MJ; GAYFORD, J; LEIGH, BC \& RAINEY, D 2003: Adolescent drinking and sex: Findings from a daily diary study. Perspectives on Sexual Health and Reproductive Health, 35(4):162-167.

MYER, L; MORRONI, C; MATHEWS, C \& LITTLE, F 2002: Dual method use in South Africa. International Family Planning Perspectives, 28(2):199-202.

NYANZI, S; POOL, R \& KINSMAN, J 2001: The negotiation of sexual relationships among school pupils in south-western Uganda. AIDS Care, 13(1):83-98.

PARKER, RG; EASTON, D \& KLEIN, CH 2000: Structural barriers and facilitators in HIV prevention: A review of international research. AIDS, 14(Supplement 1):S22-S32.

PARSONS, J; VANORA, J; MISSILDINE, W; PURCELL, DW \& GOMEZ, CA 2004: Positive and negative consequences of HIV disclosure among seropositive injection drug users. AIDS Education and Prevention, 16(5):459-475.

PATTERSON, D \& LONDON, L 2002: International law, human rights and HIVIAIDS. Bulletin of the World Health Organization, 80(12):964-969.

PETERSEN, I \& SWARTZ, L 2002: Primary health care in the era of HIV/AIDS: Some implications for health systems reform. Social Science and Medicine, 55(6):1005-1013.

PETTIFOR, AE; MEASHAM, DM; REES, HV \& PADIAN, NS 1996: Sexual power and HIV risk, South Africa. Emerging Infectious Diseases, 10(11):1996-2004.

PETTIFOR, AE; REES, HV; KLEINSCHMIDT, I; STEFFENSON, AE; MACPHAIL, C; HLONGWA-MADIKIZELA, L; VERMAAK, K \& PADIAN, NC 2005: Young people's sexual health in South Africa: HIV prevalence and sexual behaviours from a nationally representative household survey. AIDS, 19(14):1525-1534.

POTTS, M \& WALSH, J 2003: Tackling India's HIV epidemic: Lessons for Africa. British Medical Journal, 326(7403):1389-1392. PRESTON-WHYTE, EM 1995: "Bring us the female condom": HIV intervention, gender and political empowerment in two South Africa communities. Health Transition Review, 5(Supplement):209222.

RANKIN, W \& WILSON, C 2000: African women with HIV (Editorial). British Medical Journal, 321(7276):1543-1544.

REID, PT 2000: Women, ethnicity and AIDS; What's love got to do with it? Sex Roles, 42(7/8):709-723.

ROSE, J 2004: Protective behaviours: Safety, confidence and self-esteem. Journal of Mental Health Promotion, 3(1):2530.

SHEARER, CL; HOSTERMAN, SJ; GILLEN, MM \& LEFKOWITZ, ES 2005: Are traditional gender role attitudes associated with risky sexual behaviour and condom-related beliefs? Sex Roles, 52(5/ 6):311-324.

SHELTON, JD; HALPERIN, DT; NANTULYA, V; POTTS, M \& GAYLE, HD 2004: Partner reduction is crucial for balanced "ABC" approach to HIV prevention. British Medical Journal, 328(7444):891-893.

SHISANA, O \& SIMBAYI, L 2002: Nelson Mandela HSRC study of HIVIAIDS: Full report - South African national HIV prevalence, 
behavioural risks and mass media. Household Survey 2002. Pretoria: HSRC.

SHISANA, O; REHLE, T; SIMBAYI, LC; PARKER, W; ZUMA, K; BHANA, A; CONNOLLY, C; JOOSTE, S \& PILLAY, V 2005: South African national HIV prevalence, HIV incidence, behaviour and communication survey. Cape Town: HSRC Publishers.

STADLER, JJ 2003: Rumor, gossip and blame: Implications for HIVI AIDS prevention in the South African Lowveld. AIDS Education and Prevention, 15(4):357-367.

STADLER, JJ; DELANY, S \& MNTAMBO, M 2008: Women's perceptions and experiences of HIV prevention trials in Soweto, South Africa. Social Science and Medicine, 66(1):189-200. STATISTICS SOUTH AFRICA 2007: Mortality and causes of death in South Africa 2005: Findings from death notification. http:// www.statssa.gov.za/publications/P03093/P030932005.pdf. (Accessed on 14 January 2008).

STEIN, J 2003: Tackling stigma through treatment and advocacy. AIDS Bulletin, 12(1):2-3.

SWART-KRUGER, J \& RICHTER, LM 1997: Aids-related knowledge, attitudes and behaviour among South African street youth: Reflections on power, sexuality and the autonomous self. Social Science and Medicine, 45(6):957-966.

TIESSEN, R 2005: Mainstreaming gender in HIVIAIDS programs: Ongoing challenges and new opportunities in Malawi. Journal of International Women's Studies, 7(1):8-25.

UMERAH-UDEZULU, I 2001: Resensitizing African health care and policy practitioners: The gendered nature of AIDS epidemic in Africa. Jenda: A Journal of Culture and African Women Studies, 1(2):16 screens. http://www.iiav.nl/ezines/web/JENda/ Vol1(2001)Nr2/jendajournal/udezulu.pdf.

UNAIDS 2000: Innovative approaches to HIV prevention: Selected case studies. http://data.unaids.org/Publications/IRC-pub05/JC414InnovAppr_en.pdf. (Accessed on 21 October 2007).

UNAIDS 2001: Gender and AIDS almanac. http:// h i va ids c l e a ring house. un es co. org/ ev.php?ID=2228_201\&ID2=DO_TOPIC. (Accessed on 15 September 2007).

VUNDULE, C; MAFORAH, F; JEWKES, R \& JORDAAN, E 2001: Risk factors for teenage pregnancy among sexually active black adolescents in Cape Town. South African Medical Journal, 91(1):73-80.

WHITTEMORE, R \& KNAFL, K 2005: The integrative review: Updated methodology. Journal of Advanced Nursing, 52(5):546553.

WOJCICKI, JM \& MALALA, J 2001: Condom use, power and HIVI AIDS risk: Sex-workers bargain for survival in Hillbrow/Joubert Park/Berea, Johannesburg. Social Science and Medicine, 53(1):99-121.

WONG, FY; THOMPSON, EE; HUANG, ZJ; PARK, RR; DIGANGI, J \&
DE LEON, JM 2007: Alcohol, drugs, sex and HIV risk behaviours among a community sample of Black and Coloured South Africans. Journal of Drug Issues, 37(3):489-502.

WOOD, K \& JEWKES, R 1998: "Love is a dangerous thing": Microdynamics of violence in sexual relationships of young people in Umtata. Cape Town: Medical Research Council.

WOOD, K; MAEPA, J \& JEWKES, R 1997: Adolescent sex and contraceptive experiences: Perspectives of teenagers and clinic nurses in the Northern Province. Cape Town: Medical Research Council.

WOOD, K; MAFORAH, F \& JEWKES, R 1996: Sex, violence and constructions of love among Xhosa adolescents: Putting violence on the sexuality education agenda. Cape Town: Medical Research Council.

WORLD HEALTH ORGANIZATION 2008: Joint HIV/tuberculosis interventions. http://www.who.int/hiv/topics/tb/tuberculosis/en/ (Accessed on 14 May 2008).

ZELLNER, SL 2003: Condom use and the accuracy of AIDS knowledge in Cote d'Ivoire. International Family Planning Perspectives, 29(1):41-47. 